WILLIAM D. MELANEY

\title{
AESTHETIC WORLDS: RIMBAUD, WILLIAMS AND BAROQUE FORM
}

The sense of form that provides the modern poet with a unique experience of the literary object has been crucial to various attempts to compare poetry to other cultural activities. In maintaining similar conceptions of the relationship between poetry and painting, Arthur Rimbaud and W. C. Williams establish a common basis for interpreting their creative work. And yet their poetry is more crucially concerned with the sudden emergence of visible "worlds" containing verbal objects that integrate a new kind of literary text. In this paper, I shall discuss the emergence of three related aesthetic worlds: first, Rimbaud's Illuminations provides the "mythic" occasion for the eruption of post-Symbolist literature; second, Williams' Spring and All develops Rimbaud's poetics in terms of twentieth-century modernism; finally, the conception of Baroque form as explored in recent aesthetics unites Rimbaud and Williams in the shared task of overcoming Cartesian dualism.

In modern criticism, Arthur Rimbaud's poetry is often considered to be less important than that of Stéphane Mallarmé, due to its apparent indifference to metaphysical concerns and its ambiguous impact on later developments in literature. The bias against Rimbaud, however, can be challenged on the basis of both aesthetics and literary history. Mallarmé's poetry possesses obvious tonal qualities, but its musical aspects do not exhaust the interpretive possibilities that haunt the literary imagination. Mallarmé's later work, replete with typographical peculiarities and carefully wrought on the level of structure, sustains one reading of post-Symbolist poetry. Nonetheless, Rimbaud's poetry, which is perhaps more obviously engaged in emphasizing the concrete and visual aspects of experience, can be placed at the beginning of a whole "tradition of the new" that sustains a more graphic reading of subsequent literature. The difference between the two poets can be related to dissimilar conceptions of poetry: Mallarmé assumes that poetry is akin to music in its general organization and philosophical implications, whereas Rimbaud suggests that poetry is more closely related to painting in its irreducible involvement in image, color and cultural concerns. 
Mallarmé and Rimbaud are also separated in terms of an aesthetic difference that articulates a basic disagreement concerning the constitution of the self in time. Mallarmé's conception of the creative ego as phenomenologically empty retains a Cartesian significance, notwithstanding the bold gamble with common sense that quickens "Un Coup de dés." In contrast, Rimbaud's poetry incorporates a type of cogito that bespeaks a complete lack of personality and seems to be willfully inconsistent. In a famous letter to Izambard, Rimbaud praises "la poésie objective" just as he implies that objectivity coincides with a desirable kind of madness. The non-rational ego that Rimbaud embraces implies a leap into the unknown. "Je est un autre," he exclaims. ${ }^{1}$ This strange formulation states unambiguously that the ego is an other, rather than the locus of self-identity. George Poulet has argued that Rimbaud's position invokes a radical difference that opens the space between the creative ego and the ego that emerges in poetic thought. ${ }^{2}$

Rimbaud's new conception of the poetic ego underlies his interpretation of the image as a sign of objective diversity and otherness. This interpretation helps explain why Rimbaud would compare poetry to painting, rather than to music. This comparison is particularly valuable in the way that it challenges the assumption that poetry can mirror the ideal unity of self-consciousness. Rimbaud's interpretation of the poetic image rejects the vestigial idealism that late Symbolism often retains. His well-known early sonnet, "Voyelles," offers a quantitative reading of the five vowels of the alphabet. ${ }^{3}$ More significantly, Rimbaud's magisterial collection of prose poems, begun in 1872 and published by Verlaine as Les Illuminations in 1886 , employs colors in order to "flatten" a text that no longer "represents" what it signifies. ${ }^{4}$ Tzvetan Todorov argues that the collection epitomizes a refusal of representation, but should not be interpreted, for this reason, as an atemporal performance. ${ }^{5}$ Hence, just as we would be wrong to overextend Mallarmé's analogy between poetry and music, we would be wrong to assign Rimbaud's visual analogies a purely "representational" meaning.

By distorting normal perception in a manner that could have aesthetic importance, Rimbaud reminds the reader of Illuminations that external reality can become the literary aspect of a poetic world. While Mallarmé liked to dwell for long periods in an impersonal universe of Platonic Ideas, Rimbaud had recourse to a strategy of "defamiliarization" that enabled him to present the distortions of everyday life as if they were literally true. Tzvetan Todorov describes how Rimbaud's texts invite us to engage in a linguistic equivalent to the sort of visual movement suggesting that optical illusions could be 
realities: "Something at the top of the picture is said to rise; something at the bottom, to descend. Is it not possible to see this passage - by means of contiguity and not resemblance - from the image to the represented object as metonymy?"6 By alluding to the linguistic function of visual distortion in Les Illuminations, Todorov underscores the difference between Rimbaud's technique and that of his Symbolist predecessors. The decentered world of Rimbaud's poetry no longer depends on Platonic assumptions but employs a semi-narrative form that demonstrates how Romantic irony and poetic realism can be brought together in shifting cultural settings.

Todorov's insights into Rimbaud's conception of the literary text are easily corroborated through a careful reading of "Après le Déluge," the first prose poem in the Les Illuminations. ${ }^{7}$ This opening piece offers an unconventional view of a traditional theme, long familiar to painting and literature, when it adopts the moment after the flood, rather than the moment of the flood itself, as a literary starting-point. Paintings of the flood by modern artists as different as Géricault, Gustave Doré and John Martin emphasize the tremendous power of a natural event that brings complete devastation to humanity. ${ }^{8}$ Rimbaud's prose poem, in contrast, concentrates on a later moment when everything has returned to normal; it therefore seems to be anti-climactic. The small scale that Rimbaud exploits in this miniature work clearly expresses a post-Romantic conception of the artist's status in the world. However, Rimbaud's flood culminates in a second flood, namely, that of the poet's anger. Rather than relate the event of the flood to the sins of mankind, Rimbaud links the aftermath of natural devastation to various attitudes that are peculiar to everyday life. Thus, while embarking on a journey across space and time, the reader is overwhelmed by a series of images that coalesce figures and communicants, carrying him through sharp contrasts from a village square to a salon in the Alps, and then on to the earth's coldest extremities. What really interests Rimbaud, however, is not the spectacle that he deftly presents but the return of everyday people to the routines of existence. Fairy tales, biblical allusions and classical myths strangely combine in a setting that incorporates realistic detail into a poetic text of indeterminate meaning.

"Enfance," the second prose poem in the collection, assumes the form of a contrast to the normal life and also suggests that the poet cannot completely suppress his relationship to the outside world. ${ }^{9}$ The third section of this piece implicates the reader in a structure that reveals the function of the image as 
well as the text in Rimbaud's work. The repetitive use of the simple pointer, "There is" ("Il y a"), as a means for introducing an object or sighting reveals that language possesses a dual function in his writing. On the one hand, its referential function can be interpreted in terms of the relationship between poetry and painting that Rimbaud often espouses. Poetry, like painting, is concerned with "the things themselves" (den Sachen Selbst), which constitute the basis for poetic intuition. By maintaining that language provides direct access to things, Rimbaud not only breaks with a rhetorical conception of poetry, but he also prefigures a genuinely postSymbolist tradition.

Repeated allusion to what simply is can be related as well to the textual features that are peculiar to language. Language does not only refer, but also embodies in a unique way. As an embodied presence, language constantly invokes a realm of being that is merely there and can be interpreted as a text that precedes the upsurge of predicative consciousness. Poetry is uniquely capable of drawing attention to this realm of being, which indicates that plurality, otherness and difference underlie human experience.

The conception of poetry that informs "Enfance III," therefore, demonstrates how inner and outer experience can be united in a new kind of literature. A concern for denotation can be shown to be consistent in many ways with Rimbaud's participation in the Paris Commune of $1871 .{ }^{10}$ The prose poems of Les Illuminations include the description of cities, real and imaginary, everyday people in routine situations as well as barbarians who threaten to undermine the poet's own words. Rimbaud's conception of poetry constantly wavers between the evocation of a numinous present, vividly perceived, and an intimation of simultaneity that brings together different events in a sharply defined verbal collage.

Rimbaud's influence on William Carlos Williams can be clearly assessed on the basis of a short collection of twenty-seven lyrics, which were published in Paris under the title Spring and All, in 1923. The composition of this poetic sequence was preceded by the translation of Rimbaud's work into English, and also by the Anglo-American reception of Guillaume Apollinaire's important study of modernist painting, Les Peintres Cubistes: Méditations Esthétiques. Williams read both Rimbaud and Apollinaire before contributing to what might be called the anti-Symbolist moment in 
twentieth-century poetry. Williams responded to the challenge of modernism by questioning the role of representation in artistic work. Apollinaire quickly grasped the aesthetic significance of the new painting: "Cubism differs from the old schools of painting in that it aims, not at an art of imitation, but an art of conception, which tends to rise to the height of creation." 11 This affirmation of modernism is echoed in Spring and All whenever Williams celebrates the power of the imagination to constitute a world of its own according to a strict analogy between poetry and painting.

Hence, while deliberately alluding to Mallarmé's famous statement concerning the musical telos of poetry, Williams also emphasizes the transformative function of words in a way that might remind us of Rimbaud's visionary poetics. Acknowledging that writing is often compared to music, Williams offers a dynamic conception of poetic language that adopts the object-world as a starting-point for creative variation. The imaginative writer "would attain closest to the conditions of music not when his words are dissociated from natural objects but when they are liberated from the usual quality of that meaning by transposition into another medium." 12 For Williams, the Cubist revolution in painting, particularly as epitomized by the work of Pablo Picasso and Juan Gris, involved a decisive break with an aesthetic of illusion that had dominated the visual arts tradition since the early Renaissance. In his study of Cubism, Apollinaire compared the new painters to modern scientists who employ post-Euclidean mathematics in developing new models of the universe. ${ }^{13}$ Williams assigns a metaphorical meaning to Apollinaire's expression of a possible "fourth dimension" that surpasses the three dimensions of Euclidean geometry. This new realm of being is said to support reality itself through a new sense of the imagination: "It is a cleavage through everything by a force that does not exist in the mass and therefore can never be discovered by its anatomization." 14

Williams also approximates Rimbaud's use of analogies between poetry and painting through a radical use of language that challenges settled modes of cultural perception. The anti-Symbolist implications of his agenda might be expressed in terms of the Russian Formalist practice of defamiliarization. Victor Shklovsky's definition of the artistic image marks a clear advance over static conceptions of visual experience: "An image is not a permanent referent for those mutable complexities of life which are revealed through it; its purpose is not to make us perceive meaning, but to create a special perception of the object - it creates a 'vision' of the object instead of serving as a means for knowing it." 15 The practice of defamiliarization could be compared to 
what happens in the observation of a Cubist painting when our sense of the object cannot be brought into focus on the basis of a detailed presentation of pictorial elements. In referring to Picasso, Apollinaire invokes "the effort of the viewer, who is forced to see all the elements simultaneously just because of the way they have been arranged." 16 Williams employs this modernist procedure in a way that recalls Rimbaud's Illuminations, not only on the level of literary content but also through his use of a mythic narrative that results in a new vision of poetic objects.

Williams in Spring and All invokes a myth of destruction-creation that might be interpreted in terms of the Husserllian motif of the epoché, which allows the reader to assign the imagination a new significance. Rimbaud in "Après le Déluge" makes use of the biblical story of the Flood and its aftermath in order to dramatize the poet's anger and satiric perceptions of everyday life. In "Conte," he carries this theme much further by enacting the tale of a bored prince who engages in sadistic acts of destruction only to discover that the imagination has been condemned to reproduce a magnificent world that pre-exists. But it is possible to interpret this recurrent narrative as a poetic strategy that enables Rimbaud to instill in us a more vivid and intense awareness of human and natural habitats? The radical doubt that this strategy requires constitutes the basis for poetic renewal, which assumes the form of a return to the things themselves. Williams adopts this same strategy when he indicates how the perspective of destruction can be joined to a new experience of creative work: "Children laughingly fling themselves under the wheels of the street cars, airplanes crash gaily to the earth. Someone has written a poem." 17 What we are invited to experience has less to do with actual mishaps than with an act of attention that requires a new and daring use of the literary imagination.

The mythic narrative that underlies Spring and All allows Williams to renew everyday perceptions in terms of a moment of change which integrates organic and inorganic processes. For instance, the entire sequence draws upon natural images in order to suggest the idea that the universe itself exists as a field of forces in a state of constant transformation. Physical things like flowers, stars and the sea are active, energetic and verb-like, particularly when they cross from one threshold of being to the next and evade commonplace distinctions between life and death. Large-scale patterns are often exhibited according to the spatial metaphor of the edge, which functions in William's work as a crucial marker, separating one phase from another but also linking disparate items in an ever-expanding margin: "The excitement is, then, to witness the moment of change, the movement over the edge. 'Edge' 
is one of the key words in Spring and All, just as edges exist everywhere in Cubist painting." 18 The link between poetry and transformation allows William to carry the reader into a world of cosmic happenings, but also to suggest how everyday incidents can possess the power and immediacy of verbal icons. When addressing the spirit of a suicide whose body has been discovered lying on the ground, he speaks to a dark image that recalls a memorable item in Rimbaud's famous catalogue of mute things: "You seem a cathedral, celebrant of the spring which shivers for me among the long black trees."'19

III

Although their work can be studied in terms of recent literature, Rimbaud and Williams are genuine artists whose sense of form links their poetry to broad developments in the evolution of the human sensibility. It is possible to trace the literary movement from Rimbaud to Williams and beyond to the creation of a radically post-Cartesian tradition in Western poetry. Among contemporary critics, J. Hillis Miller bears eloquent testimony to the theoretical reversal that underlies William's poetic originality: "Since the world is other than the self, the self can ground itself on something external. This tradition remains valid through the nineteenth and early twentieth centuries, down to Yeats and the early Stevens. In Williams it disappears." 20 This tradition, which might be identified with the legacy of Descartes, is often assumed to include phenomenology as a modern philosophy of consciousness. However, Ludwig Landgrebe has provided an impressive account of how Husserl himself, beginning no later than the lectures on First Philosophy of 1923-24, abandoned a foundational in favor of a radically experiential conception of the human subject. ${ }^{21} \mathrm{My}$ approach to both Rimbaud and Williams assumes that a rigorous application of the phenomenological epoché can open up a post-Cartesian response to the poetic object, instead of perpetuating the heritage of modern dualism.

Moreover, the work of Rimbaud and Williams also suggests how an older tradition of aesthetic response might be brought into play as an alternative to Cartesianism, which should not be posited as constitutive for all modern thought. The Cartesian achievement was soon followed by the systems of Malebranche, Spinoza and Leibniz, whose competing conceptions of the material universe provide distinct versions of Baroque philosophy. Gilles Deleuze has suggested how for Leibniz, as opposed to Descartes, "the concept is not a simple logical being, but a metaphysical being; it is not a 
generality or a universality, but an individual; it is not defined by an attribute, but by predicates-as-events." 22 From this standpoint, the apparent nominalism of Rimbaud and Williams becomes a special trait of the Baroque sensibility. A new experience of the aesthetic can emerge when poetic illusion begins to perform an integrative function, since "the essence of the Baroque entails neither falling from illusion but rather realizing something in illusion itself, or tying it to a spiritual presence that endows its spaces and fragments with a collective unity."23

Henri Focillon's related conception of the Baroque, which attempts to describe the origin of art rather than to name a distinct period, offers new ways of interpreting the modern poetic sensibility. "Form is always, not the desire for action, but action itself," he writes. ${ }^{24}$ But this dynamic view of form can be expanded upon to embrace an experience of the past that is almost infinite. Focillon acknowledges how the significance of form cannot be restricted to the creative activity of any one time: "The Baroque of Bernini links hands with the Gothic Baroque, and it is for the frame of the tympanum, for a stone structure of the twelfth century, that the distortions and convolutions of El Greco seem to have been designed." 25 The sedimentations of artistic life provide phenomenological bases for a history of forms that embraces many centuries of human time and that comes to fruition in individual works of art. The artist's engagement with tradition points to the immanence of aesthetic experience, but it also enables the sensibility to be envisioned as a setting for transformation: "Form activates feeling. Let us say, if you like, that art not only clothes sensibility with a form, but that art also awakens form in sensibility." 26

This specifically aesthetic conception of Baroque form allows us to better understand how Rimbaud and Williams can transport us beyond a suspension of belief in a familiar world to a more challenging vision of our natural habitat. Rimbaud and Williams encompass and also surpass their respective cultural positions as modern poets in their use of language, myth and analogies between the arts. Their rejection of poetic diction and their explosive view of the relationship between words and things commit them to a new literary practice. However, the narratives of destruction and creation that the two poets employ in producing new literary works set the stage for sudden confluences of material being, which, in turn, elicit a direct intuition of sensible objects. The comparisons between poetry and painting that each poet sustains would not be tenable apart from a profound acceptance of the mysterious bond that unites experience and perception. Their work has con- 
tributed to the freedom of the human spirit in a way that is reflected in its limitless capacity to enrich phenomenological thinking.

\section{The American University in Cairo}

\section{NOTES}

1 Arthur Rimbaud, Oeuvres Complètes, p. 268.

2 Cf. George Poulet, Exploding Poetry: Baudelaire/Rimbaud, p. 103.

3 Cf. Rimbaud, "Voyelles," Oeuvres Complètes, p. 103.

4 Cf. Poulet, Exploding Poetry, p. 135.

5 Cf. Tzvetan Todorov, "Poetry Without Verse," The Prose Poem in France, p. 77.

6 Ibid., p. 77.

7 Cf. Rimbaud, “Après le Déluge," in Les Illuminations, Oeuvres Complètes, pp. 175-76.

8 Cf. C. A. Hackett, Rimbaud: A Critical Introduction, p. 53.

9 Cf. Rimbaud, "Enfance," in Les Illuminations, Oeuvres Complètes, pp. 176-178.

10 In emphasizing the political situation that influenced the poet's perception of social space, Ross argues that, unlike Mallarmé, Rimbaud was concerned with the role of denotation in language. Ross opposes this referential orientation to the role of signification in Saussurean linguistics. Cf. Kristin Ross, The Emergence of Social Space: Rimbaud and the Paris Commune, pp. 87-90. Is it possible, however, that phenomenology is perhaps uniquely capable of combining the challenge, the time and history with a critical understanding of the natural attitude?

11 Guillaume Apollinaire, The Cubist Painters: Aesthetic Meditations in Theories of Modern Art, p. 227.

12 W. C. Williams, Spring and All, in The Collected Poems of William Carlos Williams I, p. 235.

13 Cf. Apollinaire, The Cubist Painters, p. 223.

14 Williams, Spring and All, p. 225.

15 Victor Shklovsky, "Art as Technique," in Russian Formalist Criticism: Four Essays, p. 18.

16 Apollinaire, The Cubist Painters, p. 231.

17 Williams, Spring and All, p. 180.

18 Marjorie Perloff, The Poetics of Indeterminacy: Rimbaud to Cage, p. 141.

19 Williams, Spring and All, p. 181.

20 J. Hillis Miller, Poets of Reality: Six Twentieth-Century Writers, p. 288.

21 In a lucid exposition of Husserl's lectures on First Philosophy, Landgrebe emphasizes that immediate certainty must be understood in terms of absolute experience, which presumes the role of intuition in the phenomenological reduction to the transcendental ego. Landgrebe acknowledges, however, that Husserl began to turn away from Cartesianism as early as 1908: "In fact, Husserl, in all essentials, had already left the Cartesian way of establishing a foundation behind insofar as he conceived the Cartesian 'apodictic' evidence of the 'I am' together with all of the content included within it as an absolute experience, indeed, as an entire realm of experience." Cf. Ludwig Landgrebe, "Husserl's Departure from Cartesianism," in The Phenomenology of Husserl: Selected Critical Writings, p. 269.

22 Gilles Deleuze, The Fold: Leibniz and the Baroque, p. 42.

23 Deleuze, The Fold, p. 125.

24 Henri Focillon, The Life of Forms in Art, p. 45. 
25 Henri Focillon, The Art of the West in the Middle Ages, II, Gothic Art, p. 204.

26 Focillon, The Life of Forms in Art, p. 47.

\section{BIBLIOGRAPHY}

Apollinaire, Guillaume. The Cubist Painters: Aesthetic Meditations in Theories of Modern Art. Ed. Herschel B. Chipp, tr. Lionel Abel (Berkeley and Los Angeles: University of California Press, 1968), pp. 220-248.

Focillon, Henri. The Art of the West in the Middle Ages, vol. 2: Gothic Art. Ed. Jean Bony, tr. Donald King (Ithaca: Cornell University Press, 1980).

Focillon, Henri. The Life of Forms. Tr. Charles Beecher Hogan, George Kubler and S. L. Faison, Jr. (Baltimore: Monumental Printing Company, 1966).

Hackett, C. A. Rimbaud: A Critical Introduction (Cambridge: Cambridge University Press, 1981).

Heidegger, Martin. Being and Time. Tr. John Macquarrie and Edward Robinson (New York: Harper and Row, 1962).

Heidegger, Martin. On Time and Being. Tr. Joan Stambaugh (New York: Harper and Row, 1972).

Husserl, Edmund. Ideas Pertaining to a Pure Phenomenology and to a Phenomenological Philosophy, First Book: General Introduction to a Pure Phenomenology. Tr. F. Kersten (The Hague: Martinus Nijhoff Publishers, 1982).

Husserl, Edmund. Ideas Pertaining to a Pure Phenomenology and to a Phenomenological Philosophy, Second Book: Studies in the Phenomenology of Constitution. Tr. Richard Rojcewicz and André Schuwer (The Hague: Martinus Nijhoff Publishers, 1989).

Landgrebe, Ludwig. "Husserl's Departure from Cartesianism," in The Phenomenology of Husserl: Selected Critical Writings. Ed. and tr. R. O. Elveton (Chicago: Quadrangle Books, 1970), pp. 259-306.

Miller, J. Hillis. Poets of Reality: Six Twentieth-Century Writers (Cambridge, MA: Harvard University Press, 1965).

Perloff, Marjorie. The Poetics of Indeterminacy: Rimbaud to Cage (Princeton: Princeton University Press, 1981).

Poulet, George. Exploding Poetry: Baudelaire/Rimbaud. Tr. François Meltzer (Chicago: University of Chicago Press, 1984).

Rimbaud, Arthur. Oeuvres Complètes d'Arthur Rimbaud (Paris: Librairie Galllimard, 1954).

Ross, Kristin. The Emergence of Social Space: Rimbaud and the Paris Commune (Minneapolis: University of Minnesota Press, 1988).

Schklovsky, Victor. "Art as Technique," in Russian Formalist Criticism: Four Essays. Tr. Lee T. Lemon and Marion J. Reis (Lincoln: University of Nebraska Press, 1965), pp. 3-57.

Todorov, Tzevtan. "Poetry Without Verse," in The Prose Poem in France (New York: Columbia University Press, 1983), pp. 60-78.

Williams, William Carlos. Spring and All, in The Collected Poems of William Carlos Williams, vol. I: 1909-1939. Ed. A. Walton Litz and Christopher MacGowan (New York: New Directions Publishing, 1986), pp. 175-236. 